\title{
Cyclization Reactions of Ruthenium Vinylidene Complexes
}

\author{
Chao-Wan Chang, Ying-Chih Lin,* Gene-Hsiang Lee, and Yu Wang
}

Department of Chemistry, National Taiwan University, Taipe, Taiwan 106, Republic of China

Received March 22, 1999

Treatment of $[\mathrm{Ru}]-\mathrm{C}=\mathrm{C}(\mathrm{Ph}) \mathrm{C}(=\mathrm{NPh}) \mathrm{S}\left(\mathbf{2},[\mathrm{Ru}]=\left(\eta^{5}-\mathrm{C}_{5} \mathrm{H}_{5}\right)(\mathrm{dppe}) \mathrm{Ru}, \mathrm{dppe}=\mathrm{Ph}_{2} \mathrm{PCH}_{2^{-}}\right.$ $\mathrm{CH}_{2} \mathrm{PPh}_{2}$ ) with $1 \mathrm{CH}_{2} \mathrm{CN}$ at room temperature affords the S-alkylation product $[\mathrm{Ru}]=\mathrm{C}=$ $\mathrm{C}(\mathrm{Ph}) \mathrm{C}(=\mathrm{NPh}) \mathrm{SCH}_{2} \mathrm{R}^{+}(3 \mathrm{a}, \mathrm{R}=\mathrm{CN})$. Deprotonation of $3 \mathrm{a}$ by $\mathrm{n}-\mathrm{Bu}_{4} \mathrm{NOH}$ in acetone induces a novel cyclization reaction and yields the neutral five-membered-ring heterocyclic complex $[\mathrm{Ru}]-\mathrm{C}=\mathrm{C}(\mathrm{Ph}) \mathrm{C}(=\mathrm{NPh}) \mathrm{SCHCN}(\mathbf{5 a})$, which isomerizes to the 2-aminothiophene complex $[\mathrm{Ru}]-\mathrm{C}=\mathrm{C}(\mathrm{CN}) \mathrm{SC}(\mathrm{NHPh})=\mathrm{C}(\mathrm{Ph})(\mathbf{6 a})$. Treatment of $\mathbf{2}$ with organic bromides $\mathrm{BrCH}_{2} \mathrm{R}$ affords both S-alkylation products ( $3 \mathbf{b}, \mathrm{R}=\mathrm{CO}_{2} \mathrm{CH}_{3} ; \mathbf{3 c}, \mathrm{R}=\mathrm{p}-\mathrm{C}_{6} \mathrm{H}_{4} \mathrm{CN} ; \mathbf{3 d}, \mathrm{R}=\mathrm{Ph}$ ) and N-alkylation products $[\mathrm{Ru}]=\mathrm{C}=\mathrm{C}(\mathrm{Ph}) \mathrm{C}(=\mathrm{S}) \mathrm{NPhCH}_{2} \mathrm{R}^{+}\left(\mathbf{4 b}, \mathrm{R}=\mathrm{CO}_{2} \mathrm{CH}_{3} ; \mathbf{4 c}, \mathrm{R}=\mathrm{p}-\mathrm{C}_{6} \mathrm{H}_{4} \mathrm{CN} ; \mathbf{4 d}, \mathrm{R}=\right.$ $\mathrm{Ph}$ ) in varying ratios. Base-induced cyclization of a mixture of $\mathbf{3 b}$ and $\mathbf{4 b}$ occurs only for the 3b component to afford $[\mathrm{Ru}]-\mathrm{C}=\mathrm{C}(\mathrm{Ph}) \mathrm{C}(=\mathrm{NPh}) \mathrm{SCHCO}_{2} \mathrm{CH}_{3}(\mathbf{5 b})$, whereas cyclization of a mixture of $\mathbf{3 c}$ and $\mathbf{4 c}$ occurs for both complexes, yiel ding $\mathbf{5 c}$ and the pyrrole-2-thione complex $[\mathrm{Ru}]-\mathrm{C}=\mathrm{C}(\mathrm{Ph}) \mathrm{C}(=\mathrm{S}) \mathrm{N}(\mathrm{Ph}) \mathrm{CH}\left(\mathrm{p}-\mathrm{C}_{6} \mathrm{H}_{4} \mathrm{CN}\right)(\mathbf{7 c})$, respectively. Cyclization of a $\mathbf{3 d}-\mathbf{4 d}$ mixture occurs only for $\mathbf{4 d}$ to afford $[\mathrm{Ru}]-\mathrm{C}=\mathrm{C}(\mathrm{Ph}) \mathrm{C}(=\mathrm{S}) \mathrm{NPhCHPh}(\mathbf{7 d})$. The structures of $\mathbf{6} \mathbf{a}$ and 7c were determined by single-crystal $\mathrm{X}$-ray diffraction analysis.

\section{Introduction}

Metal acetylide complexes has been the focus of many recent studies because of their applications in organometallic ${ }^{1-4}$ and materials $\mathrm{s}^{5-8}$ chemistry. A common reaction of a metal acetylide is a [2 + 2] cycloaddition of the triple bond with unsaturated organic substrates, ${ }^{9}$ such as $\mathrm{CS}_{2},{ }^{10-12}(\mathrm{NC})_{2} \mathrm{C}=\mathrm{C}\left(\mathrm{CF}_{3}\right)_{2}$, and $(\mathrm{NC})_{2} \mathrm{C}=$ $\mathrm{C}(\mathrm{CN})_{2} \cdot{ }^{13-15}$ Recently we reported ${ }^{16}$ a similar cycloaddition reaction of the ruthenium acetylide complex $\{\mathrm{Ru}\} \mathrm{C} \equiv \mathrm{CPh}\left(\mathbf{1}^{\prime},\{\mathrm{Ru}\}=\left(\eta^{5}-\mathrm{C}_{5} \mathrm{H}_{5}\right)\left(\mathrm{PPh}_{3}\right)\left[\mathrm{P}(\mathrm{OMe})_{3}\right] \mathrm{Ru}\right)$

(1) Beck, W.; Niemer, B.; Wieser, M. Angew. Chem., Int. Ed. Engl. 1993, 32, 923.

(2) Hegedus, L. S. In Organometallics in Synthesis; Schlosser, M., Ed,; Wiley: New York, 1994; p 383.

(3) Bartik, T.; Bartik, B.; Brady, M.; Dembinski, R.; Gladysz, J . A. Angew. Chem., Int. Ed. Engl. 1996, 35, 414.

(4) Ting, P. C.; Lin, Y. C.; Lee, G. H.; Cheng, M. C.; Wang, Y. J . Am. Chem. Soc. 1996, 118, 6344.

(5) Myers, L. K.; Langhoff, C.; Thompson, M. E. J . Am. Chem. Soc. 1992, 114, 7560.

(6) Kaharu, T.; Matsubara, H. Tajahashi, S. J . Mater. Chem. 1992, $2,43$.

(7) Lavastre, O.; Even, M.; Dixneuf, P. H.; Pacreau, A.; Vairon, J P. Organometallics 1996, 15, 1530.

(8) Wu, I. Y.; Lin, J . T.; Luo, J .; Sun, S. S.; Li, C. S.; Lin, K.J .; Tsai,

C.; Hsu, C. C.; Lin, J . L. Organometallics 1997, 16, 2038.

(9) Bruce, M. I.; Hambley, T. W.; Leddell, M. J .; Snow, M. R.; Swincer, A. G.; Tiekink, R. T. Organometallics 1990, 9, 96.

(10) Selegue, J. P. J. Am. Chem. Soc. 1982, 104, 119.

(11) Birdwhistell, K. R.; Templeton, J . L. Organometallics 1985, 4, 2062.

(12) Selegue, J . P.; Young, B. A.; Logan, S. L. Organometallics 1991, 10, 1972.

(13) Davison, A,; Solar, J. P. J. Organomet. Chem. 1979, 166, C13. (14) Bruce, M. I.; Hambley, T. W.; Snow, M. R.; Swincer, A. G. Organometallics 1985, 4, 501.

(15) Barrett, A. G. M.; Carpenter, N. E.; Mortier, J .; Sabat, M. Organometallics 1990, 9, 151.

(16) Chang, C. W.; Lin, Y. C.; Lee, G. H.; Huang, S. L.; Wang, Y. Organometallics 1998, 17, 2534. with isothiocyanates RNCS to afford $\{\mathrm{Ru}\} \mathrm{C}=\mathrm{C}(\mathrm{Ph}) \mathrm{C}$ $(=\mathrm{NR}) \mathrm{S}\left(\mathbf{2}^{\prime}\right)$. This cycloaddition was found to be reversible, and in the absence of free isothiocyanate, the acetyl ide complex was gradual ly regenerated. However, in the presence of excess isothiocyanate, the sixmembered-ring complex $\{\mathrm{Ru}\} \mathrm{C}=\mathrm{C}(\mathrm{Ph}) \mathrm{C}(=\mathrm{S}) \mathrm{N}(\mathrm{R}) \mathrm{C}(=$ $\mathrm{NR}) \mathrm{S}$, containing two isothiocyanate molecules, was obtained. This indicates that the reversed cycloaddition is a stepwise process. Formation of the six-memberedring complex was thus rationalized by opening of the four-member ed ring of $\boldsymbol{2}$ via cleavage of the $\mathrm{C}_{\alpha}-\mathrm{S}$ bond, foll lowed by coupling of a second isothiocyanate molecule. Opening of the four-membered ring of $\mathbf{\alpha}$ could provide a zwitterionic complex with the negative charge localized at one of the heteroatoms ( $\mathrm{S}$ and $\mathrm{N}$ ), and a subsequent alkylation reaction at the heteroatom site could be a useful reaction. We therefore reacted alkyl halides with the dppe analogue of the four-memberedring complex. Herein we report that these alkylation reactions yield a number of vinylidene complexes. ${ }^{17-21}$ Subsequent deprotonation-induced-cyclization reactions of these vinylidene complexes form neutral heterocyclopentenyl complexes. ${ }^{4,22}$

(17) Bruce, M. I. Chem. Rev. 1991, 91, 197. 59.

(18) Bruce, M. I.; Swincer, A. G. Adv. Organomet. Chem. 1983, 22,

(19) Davies, S. G.; McNally, J . P.; Smallridge, A. J . Adv. Organomet. Chem. 1990, 30, 1.

(20) Kostic, N. M.; Fenske, R. F. Organometallics 1982, 1, 974.

(21) Werner, H.; Wolf, J .; Muller, G.; Krüger, C. Angew. Chem., Int. Ed. Engl. 1984, 28, 431.

(22) Chang, C. W.; Ting, P. C.; Lin, Y. C.; Lee, G. H.; Wang, Y. J Organomet. Chem. 1998, 553, 417. 


\section{Scheme 1}

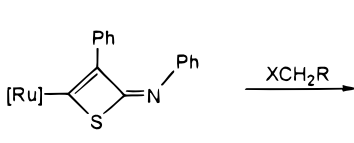

2
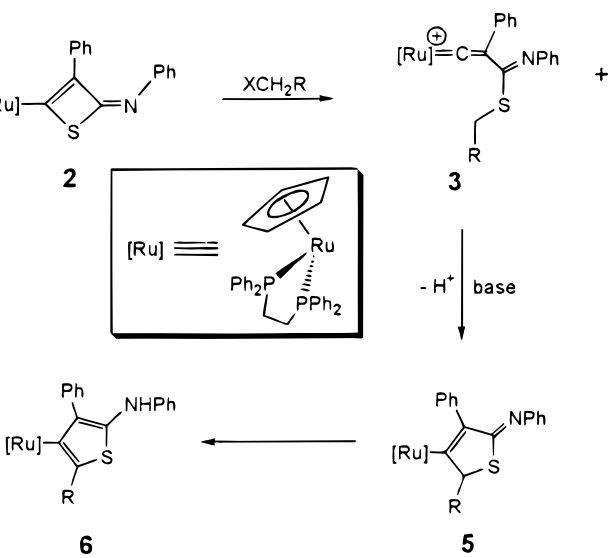

Results and Discussion

Synthesis of Vinylidene Complexes. Treatment of $[\mathrm{Ru}] \mathrm{C} \equiv \mathrm{CPh}\left(\mathbf{1},[\mathrm{Ru}]=\left(\eta^{5}-\mathrm{C}_{5} \mathrm{H}_{5}\right)(\mathrm{dppe}) \mathrm{Ru}, \mathrm{dppe}=\mathrm{Ph}_{2^{-}}\right.$ $\mathrm{PCH}_{2} \mathrm{CH}_{2} \mathrm{PPh}_{2}$ ) with PhNCS in $\mathrm{CH}_{2} \mathrm{Cl}_{2}$ at room temperature for 3 days affords the yellow [2 +2$]$ cycload-

dition product $[\mathrm{Ru}]-\mathrm{C}=\mathrm{C}(\mathrm{Ph}) \mathrm{C}(=\mathrm{NPh}) \mathrm{S}(\mathbf{2}){ }^{23-26}$ On the basis of the chemical reactivity of the bis(triphenylphosphine) analogue of $2,{ }^{16}$ we believe that $\mathbf{2}$ exists in two forms: a four-membered-ring structure and a zwitterionic structure formed by cleavage of the $\mathrm{C}_{\alpha}-\mathrm{S}$ bond of the four-membered ring. In the zwitterionic form the negative charge could be localized either at the $\mathrm{S}$ atom or at the $\mathrm{N}$ atom, thus rendering these atoms nucleophilic. Indeed, treatment of $\mathbf{2}$ with $\mathrm{ICH}_{2} \mathrm{CN}$ affords the air-stable cationic vinylidene complex $\{[\mathrm{Ru}]=\mathrm{C}=\mathrm{C}(\mathrm{Ph}) \mathrm{C}$ $\left.(=\mathrm{NPh}) \mathrm{SCH}_{2} \mathrm{CN}\right\}[\mathrm{I}]$ (3a) in $87 \%$ yield. The alkylation is found to take place only at the $\mathrm{S}$ atom. The vinylidene ligand of $\mathbf{3 a}$ was confirmed by the presence of a triplet ${ }^{13} \mathrm{C}$ resonance at $\delta 340.7$ with J $\mathrm{C}-\mathrm{P}=13.4 \mathrm{~Hz}$ assignable to $\mathrm{C}_{\alpha}$. The ${ }^{31 \mathrm{p}}$ resonance of $3 \mathbf{a}$ appears as a singlet at $\delta$ 78.1 due to the fluxional behavior of the vinylidene ligand. Interestingly, unlike other orange-red ruthenium vinylidene complexes, $\mathbf{3 a}$ is purple.

Treatment of complex 2 with $\mathrm{BrCH}_{2} \mathrm{CO}_{2} \mathrm{CH}_{3}$ in $\mathrm{CH}_{2-}$ $\mathrm{Cl}_{2}$ affords a mixture of two cationic vinylidene complexes, the S-alkylation product $[\mathrm{Ru}]=\mathrm{C}=\mathrm{C}(\mathrm{Ph}) \mathrm{C}(=\mathrm{NPh})$ $\mathrm{SCH}_{2} \mathrm{CO}_{2} \mathrm{CH}_{3}{ }^{+}(3 \mathbf{b})$ and the $\mathrm{N}$-alkylation product $[\mathrm{Ru}]=$ $\mathrm{C}=\mathrm{C}(\mathrm{Ph}) \mathrm{C}(=\mathrm{S}) \mathrm{N}(\mathrm{Ph}) \mathrm{CH}_{2} \mathrm{CO}_{2} \mathrm{CH}_{3}+$ (4b) (Scheme 1), in a ratio of $3: 2$ and with a total yield of $78 \%$. The ratio of $\mathbf{3 b}$ to $\mathbf{4 b}$ depends on the reaction temperature, with $\mathbf{3 b}$ favored at lower temperature. Under reflux conditions, the $\mathbf{3 b} \mathbf{b} \mathbf{4 b}$ ratio was found to be ca. $\mathbf{1 : 1}$. Complexes $\mathbf{3 b}$ and $\mathbf{4 b}$ do not interconvert in solution and could not be separated by chromatography. The ${ }^{31}$ P NMR spectrum of the mixture displays two singlet resonances at $\delta 77.2$ and 79.0 attributed to $\mathbf{3 b}$ and $\mathbf{4} \mathbf{b}$, respectively. In the ${ }^{1} \mathrm{H}$ NMR spectrum two resonances at $\delta 5.52$ and 5.48 are assigned to the $\mathrm{Cp}$ groups of $\mathbf{3 b}$ and $\mathbf{4} \mathbf{b}$, and resonances at $\delta 3.45$ and 3.43 are assigned to the $\mathrm{CH}_{2}$ groups of $\mathbf{3 b}$ and $\mathbf{4 b}$, respectively. In the ${ }^{13} \mathrm{C} N M R$

(23) Yih, K. H.; Lin, Y. C.; Cheng, M. C.; Wang, Y. J . Chem. Soc., Chem. Commun. 1993, 1380

(24) Yih, K. H.; Lin, Y. C.; Cheng, M. C.; Wang, Y. J . Chem. Soc., Dalton Trans. 1995, 1305.

(25) Yih, K. H.; Yeh, S. C.; Lin, Y. C.; Lee, G. H.; Wang, Y. Organometallics 1998, 17, 513.

(26) Chang, C. W.; Ting, P. C.; Lin, Y. C.; Lee, G. H.; Wang, Y. J. Organomet. Chem. 1998, 553, 417. spectrum of the mixture, two triplet resonances at $\delta$ $341.5(\mathrm{~J}-\mathrm{p}=18.2 \mathrm{~Hz})$ and $342.2(\mathrm{~J} \mathrm{c-p}=17.7 \mathrm{~Hz})$ are assigned to C $\alpha$ 's of $\mathbf{3 b}$ and $\mathbf{4 b}$, respectively, indicating that both are vinylidene complexes.

Other vinylidene complexes $[\mathrm{Ru}]=\mathrm{C}=\mathrm{C}(\mathrm{Ph}) \mathrm{C}(=\mathrm{NPh})$ $\mathrm{SCH}_{2} \mathrm{R}^{+}\left(3 \mathrm{c}, \mathrm{R}=\mathrm{p}-\mathrm{C}_{6} \mathrm{H}_{4} \mathrm{CN}\right.$; 3d, $\left.\mathrm{R}=\mathrm{Ph}\right)$ and $[\mathrm{Ru}]=$ $\mathrm{C}=\mathrm{C}(\mathrm{Ph}) \mathrm{C}(=\mathrm{S}) \mathrm{N}(\mathrm{Ph}) \mathrm{CH}_{2} \mathrm{R}^{+}\left(\mathbf{4 c}, \mathrm{R}=\mathrm{p}-\mathrm{C}_{6} \mathrm{H}_{4} \mathrm{CN} ; \mathbf{4 d}, \mathrm{R}\right.$ $=\mathrm{Ph}$ ) were similarly prepared as mixtures at room temperature $(\mathbf{3 c}: \mathbf{4 c}=1: 2$, total yield $87 \% ; \mathbf{3 d : 4 d}=6: 5$, total yield $83 \%$ ) by reacting 2 with organic bromides (Scheme 1). Alkylation reactions take place both at the $\mathrm{N}$ and the $\mathrm{S}$ atoms. Like $\mathbf{3 a}$ and $\mathbf{3 b}$, complexes $\mathbf{3 c}, \mathbf{4 c}$, $\mathbf{3 d}$, and $\mathbf{4 d}$ are all purple, air stable and thermally stable, soluble in polar solvents such as $\mathrm{CHCl}_{3}, \mathrm{CH}_{2-}$ $\mathrm{Cl}_{2}$, acetone, and $\mathrm{THF}$, and insoluble in ether and hexane. Generally complexes $\mathbf{3}$ and $\mathbf{4}$ are not separable by column chromatography. However, as described below, pure complexes can be obtained indirectly.

Deprotonation-Induced Cyclization of Vinylidene Complex 3a. Treatment of $3 a$ with n- $\mathrm{Bu}_{4} \mathrm{NOH}$ (1M in $\mathrm{MeOH}$ ) causes deprotonation of the methylene group, followed by a cyclization reaction affording the neutral complex $[\mathrm{Ru}]-\mathrm{C}=\mathrm{C}(\mathrm{Ph}) \mathrm{C}(=\mathrm{NPh}) \mathrm{SCHCN}$ (5a) (Scheme 1). Protonation of $5 \mathbf{a}$ in $\mathrm{CHCl}_{3}$ with $\mathrm{CF}_{3} \mathrm{COOH}$ immediately gives 3 a in quantitative yield. In our attempt to purify $\mathbf{5 a}$ by column chromatography, isomerization to the 2-aminothiophene complex $[\mathrm{Ru}]-\mathrm{C}=\mathrm{C}(\mathrm{CN}) \mathrm{SC}$ $(\mathrm{NHPh})=\mathrm{CPh}(\mathbf{6 a})$ takes place. This conversion also occurs in benzene at room temperature in $3 \mathrm{~h}$. No reaction was observed between complex $6 \mathbf{a}$ and el ectrophiles such as $\mathrm{CH}_{3} \mathrm{I}, \mathrm{ICH} \mathrm{CH}_{2} \mathrm{CN}$, and $\mathrm{CH}_{3} \mathrm{COOH}$. The transformation of $\mathbf{5 a}$ to $\mathbf{6 a}$ possibly proceeds via a hydrogen shift process. When the reaction is carried out at an appropriate concentration, single crystals of $\mathbf{6 a}$ suitable for X-ray diffraction analysis can be obtained directly. The ${ }^{31} \mathrm{P}$ NMR spectrum of $\mathbf{5} \mathbf{a}$ shows two doublet resonances at $\delta 72.30$ and 69.12 with J $\mathrm{p}-\mathrm{p}=29.76 \mathrm{~Hz}$ due to the presence of an asymmetric carbon center in the five-membered ring. The ${ }^{31 P}$ NMR spectrum of $\mathbf{6 a}$ displays a broad resonance at $\delta 67.55$ at room temperature which resolves into two doublets at $\delta 71.76$ and 60.78 with J p-p $=32.6 \mathrm{~Hz}$ at $-80{ }^{\circ} \mathrm{C}$, possibly due to the hindered flipping of the pyramidal nitrogen atom.

The structure of $\mathbf{6} \mathbf{a}$ has been confirmed by a single crystal X-ray diffraction study. An ORTEP diagram is shown in Figure 1 , and selected bond distances and bond angles are given in Table 1 . This complex adopts a distorted three-legged piano-stool geometry with the $\mathrm{P} 1-\mathrm{Ru}-\mathrm{P} 2, \mathrm{P} 1-\mathrm{Ru}-\mathrm{C} 1$, and $\mathrm{P} 2-\mathrm{Ru}-\mathrm{C} 1$ angles being 83.30(3), 116.96(11), and 99.26(9) ${ }^{\circ}$, respectively. The metal center is coordinated to an $\mathrm{sp}^{2} \mathrm{C} 4$ carbon of the substituted 2-aminothiophene ligand. The $\mathrm{Ru}-\mathrm{Cl}$ distance of $2.112(3) \AA$ is typical for a Ru-C single bond, and the $\mathrm{C} 1-\mathrm{C} 2$ distance of $1.445(5) \AA$ is slightly longer than that of a $\mathrm{C}-\mathrm{C}$ double bond. Two other $\mathrm{C}-\mathrm{C}$ bonds (1.390(5) $\AA$ for $\mathrm{C} 1-\mathrm{C} 4$ and $1.387(5) \AA$ for $\mathrm{C} 2-\mathrm{C} 3$ ) indicate double bonds. The $\mathrm{Ru}-\mathrm{C} 1-\mathrm{C} 2$ angle is $129.7-$ $(2)^{\circ}$, and the $\mathrm{Ru}-\mathrm{C} 1-\mathrm{C} 4$ angle is $121.0(2)^{\circ}$, close to that expected for $\mathrm{C}\left(\mathrm{sp}^{2}\right)$ hybridization. The $\mathrm{C} 3-\mathrm{N} 1$ distance of 1.379(4) $\AA$ indicates a single bond. The bond distances C4-S1 and C3-S1 of 1.755(4) and 1.724(4) A, respec- 


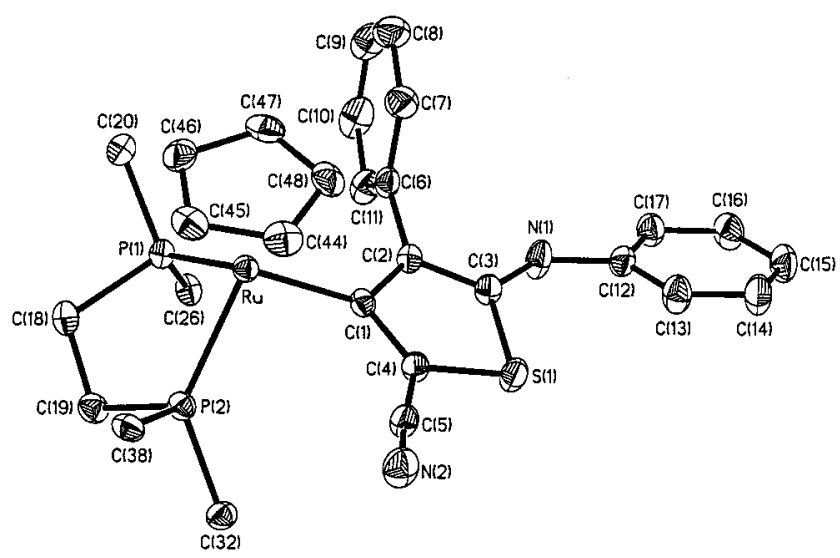

Figure 1. ORTEP drawing of $\mathbf{6 a}$ with thermal ellipsoids shown at the $30 \%$ probability level. For the dppe phenyl groups, only the ipso carbons are shown.

Table 1. Selected Bond Distances $(\AA)$ and Angles (deg) for $\mathrm{Cp}(\mathrm{dppe}) \mathrm{Ru}-\mathrm{C}=\mathrm{C}(\mathrm{CN}) \mathrm{SC}(\mathrm{NHPh})=\mathrm{CPh}$ (6a)

$\begin{array}{lllr}\text { Ru-C1 } & 2.112(3) & \mathrm{C} 1-\mathrm{C} 2 & 1.445(5) \\ \mathrm{Ru}-\mathrm{P} 1 & 2.2747(10) & \mathrm{C} 1-\mathrm{C} 4 & 1.390(5) \\ \mathrm{Ru}-\mathrm{P} 2 & 2.3103(9) & \mathrm{C} 2-\mathrm{C} 3 & 1.387(4) \\ \mathrm{S} 1-\mathrm{C} 1 & 1.724(4) & \mathrm{C} 4-\mathrm{C} 5 & 1.412(5) \\ \mathrm{S} 1-\mathrm{C} 4 & 1.755(4) & \mathrm{N} 1-\mathrm{C} 12 & 1.402(5) \\ \mathrm{N} 1-\mathrm{C} 3 & 1.379(4) & \mathrm{N} 2-\mathrm{C} 5 & 1.153(5) \\ \mathrm{P} 1-\mathrm{Ru}-\mathrm{P} 2 & 83.30(3) & \mathrm{C} 4-\mathrm{S} 1-\mathrm{C} 3 & 89.9(2) \\ \text { P1-Ru-C1 } & 116.96(11) & \mathrm{S} 1-\mathrm{C} 3-\mathrm{C} 2 & 112.2(3) \\ \text { P2-Ru-C1 } & 99.26(9) & \mathrm{C} 1-\mathrm{C} 2-\mathrm{C} 3 & 114.8(3) \\ \text { Ru-C1-C4 } & 121.0(2) & \mathrm{C} 2-\mathrm{C} 3-\mathrm{N} 1 & 124.5(3) \\ \text { Ru-C1-C2 } & 129.7(2) & \mathrm{S} 1-\mathrm{C} 3-\mathrm{N} 1 & 123.3(3) \\ \text { C2-C1-C4 } & 108.0(3) & \mathrm{C} 3-\mathrm{N} 1-\mathrm{C} 12 & 131.8(3) \\ \text { C1-C4-S1 } & 115.0(3) & \mathrm{C} 4-\mathrm{C} 5-\mathrm{N} 2 & 175.6(4) \\ \mathrm{C} 3-\mathrm{C} 2-\mathrm{C} 6 & 115.7(3) & \mathrm{C} 1-\mathrm{C} 4-\mathrm{C} 5 & 129.3(3) \\ \mathrm{C} 5-\mathrm{C} 4-\mathrm{S} 1 & 115.2(3) & & \end{array}$

tively, are typical of a $\mathrm{C}-\mathrm{S}$ single bond. ${ }^{27} \mathrm{The} \mathrm{C} 2-\mathrm{C} 3-$ $\mathrm{S} 1$ angle is $112.2(3)^{\circ}$, and the $\mathrm{C} 1-\mathrm{C} 4-\mathrm{S} 1$ angle is $115.0(3)^{\circ}$. The $\mathrm{C} 3-\mathrm{S} 1-\mathrm{C} 4$ angle of $89.9(2)^{\circ}$ is smaller than that of a typical acyclic $\mathrm{C}-\mathrm{S}-\mathrm{C}$ angle.

Deprotonation-Induced Cyclization of Vinylidene Complexes $3 b, 3 c$, and $4 c$. Treatment of a mixture of $\mathbf{3 b}$ and $\mathbf{4 b}$ in $\mathrm{CH}_{2} \mathrm{Cl}_{2}$ with $\mathrm{NaOMe}$ causes a color change from purple to orange-yellow. The ${ }^{31 P}$ NMR spectrum of the orange-yellow solution displays two doublet resonances at $\delta 73.4$ and 64.5 with J $\mathrm{p}-\mathrm{p}=28.8 \mathrm{~Hz}$ and a singlet resonance at $\delta$ 94.0. The former set is at-

tributed to $[\mathrm{Ru}]-\mathrm{C}=\mathrm{C}(\mathrm{Ph}) \mathrm{C}(=\mathrm{NPh}) \mathrm{SCH}\left(\mathrm{CO}_{2} \mathrm{CH}_{3}\right)(\mathbf{5 b})$ and the latter to complex $\mathbf{2}$. The ratio of $\mathbf{5 b}$ to $\mathbf{2}$ is the same as that of $\mathbf{3 b}$ to $\mathbf{4 b}$, indicating that formations of $\mathbf{5 b}$ and $\mathbf{2}$ are derived from $\mathbf{3 b}$ and $\mathbf{4 b}$, respectively. Under the reaction conditions, the organic portion $\left(\mathrm{CH}_{2-}\right.$ $\mathrm{CO}_{2} \mathrm{CH}_{3}$ ) of $\mathbf{4} \mathbf{b}$ was removed to give $\mathbf{2}$. Complexes $\mathbf{5 b}$ and $\mathbf{2}$ were separated by column chromatography; $\mathbf{5 b}$ decomposes at room temperature in 2 days in $\mathrm{CH}_{2} \mathrm{Cl}_{2}$. Treatment of a mixture of $\mathbf{3 b}$ and $\mathbf{4 b}$ with DBU (1,8diazabicyclo[5,4,0]undecene) or $\mathrm{n}-\mathrm{Bu}_{4} \mathrm{NOH}$ also yielded a mixture of $\mathbf{5 b}$ and $\mathbf{2}$. Isomerization of $\mathbf{5 b}$ to the 2 -aminothiophene complex $\mathbf{6 b}$ occurs in solution. As with $\mathbf{6 a}$, complex $\mathbf{6 b}$ has a broad ${ }^{31} \mathrm{p}$ resonance at $\delta$ 65.10 at room temperature that at $-40{ }^{\circ} \mathrm{C}$ resolves into two doubletsat $\delta 69.73$ and 58.66 with J $\mathrm{p}-\mathrm{p}=32.2 \mathrm{~Hz}$.

(27) Orpen, A. G.; Brammer, L.; Allen, F. H.; Kennard, O.; Watson, D. G.; Taylor, R. J . Chem. Soc., Dalton Trans. 1989, S1.
When the mixture of $\mathbf{3 c}$ and $\mathbf{4 c}$ was treated with $n-\mathrm{Bu}_{4} \mathrm{NOH}$, an immediate color change from purple to yellow was observed. I nterestingly, the deprotonationinduced cyclization occurred for both $\mathbf{3 c}$ and $\mathbf{4 c}$, giving $[\mathrm{Ru}]-\mathrm{C}=\mathrm{C}(\mathrm{Ph}) \mathrm{C}(=\mathrm{NPh}) \mathrm{SC} H\left(\mathrm{p}-\mathrm{C}_{6} \mathrm{H}_{4} \mathrm{CN}\right)(5 \mathrm{c})$ and $[\mathrm{Ru}]-$ $\mathrm{C}=\mathrm{C}\left(\mathrm{p}-\mathrm{C}_{6} \mathrm{H}_{4} \mathrm{CN}\right) \mathrm{SC}(\mathrm{NHPh})=\mathrm{CPh}(\mathbf{7 c})$, respectively. The 31P NMR spectrum of the reaction mixture displays two pairs of doublet resonances: one appears at $\delta 69.31$ and 67.54 with J $p-p=30.9 \mathrm{~Hz}$, assignable to $\mathbf{5 c}$, and the other at $\delta 94.88$ and 91.79 with $J_{\mathrm{p}-\mathrm{p}}=18.3 \mathrm{~Hz}$, assignable to 7c. Both patterns arise from the asymmetric five-membered ring in $\mathbf{5 c}$ and $\mathbf{7 c}$. These two compl exes could be separated by chromatography using an alumina column. The ${ }^{1} \mathrm{H}$ NMR spectrum of $\mathbf{5 c}$ shows resonances at $\delta 3.77$ and 3.58 assignable to $\mathrm{Cp}$ and $\mathrm{CH}$ groups, respectively. Complex $5 \mathrm{c}$ is stable at $-20^{\circ} \mathrm{C}$ but transforms to the corresponding 2-aminothiophene complex $\mathbf{6 c}$ in solution at room temperature in 3 days. Heating a solution of $\mathbf{5 c}$ accelerates this conversion. The 31P NMR spectrum of $\mathbf{6 c}$ displays an AX pattern at $\delta$ 72.15 and 66.40 with J $\mathrm{p}-\mathrm{p}=28.8 \mathrm{~Hz}$. In the ${ }^{1} \mathrm{H}$ NMR spectrum of $\mathbf{6 c}$, the $C p$ resonance appears at $\delta 3.47$ and the $\mathrm{NH}$ resonance at $\delta 5.84$. Protonation of $5 \mathrm{c}$ with excess $\mathrm{CF}_{3} \mathrm{COOH}$ yielded $3 \mathrm{c}$.

Deprotonation-Induced Cyclization of Vinylidene Complex $\mathbf{4 d}$. Treatment of a mixture of $\mathbf{3 d}$ and $\mathbf{4 d}$ with $\mathrm{NaOMe}$ affords directly $[\mathrm{Ru}]-\mathrm{C}=\mathrm{C}(\mathrm{Ph}) \mathrm{C}(=\mathrm{S}) \mathrm{N}(\mathrm{Ph}) \mathrm{CH}$ $\mathrm{Ph}$ (7d), with no reaction occurring between $\mathbf{3 d}$ and $\mathrm{NaOMe}$. Complex $\mathbf{7 d}$ is unstable and can be separated from 3d by extraction with hexane. Complex 7d was also obtained by treatment of the mixture of $\mathbf{3 d}$ and $\mathbf{4 d}$ with $\mathrm{n}-\mathrm{Bu}_{4} \mathrm{NOH}$.

Facile deprotonation shows the acidic nature of the methylene protons of $\mathbf{3 a}-\mathbf{c}$, which may be ascribed predominantly to the cationic character of the vinylidene complexes. It is not known why $\mathbf{3 d}$ will not undergo deprotonation. Generally deprotonation of $\mathbf{4 c}$ and $\mathbf{4 d}$ is faster than that of $\mathbf{3}$. The resulting complexes $\mathbf{7 c}$ and 7d are yellowish solids and are soluble in $\mathrm{CH}_{2} \mathrm{Cl}_{2}$, acetone, benzene, and ether. Complex 7c is stable in acetone and in $\mathrm{CHCl}_{3}$ for 7 days, while $\mathbf{7 d}$ is relatively less stable in solution and decomposes in $\mathrm{CHCl}_{3}$ in $8 \mathrm{~h}$ at room temperature. Both $\mathbf{7 c}$ and $\mathbf{7 d}$ react with acids such as $\mathrm{CH}_{3} \mathrm{COOH}$ and $\mathrm{CF}_{3} \mathrm{COOH}$ to give $\mathbf{4 c}$ and $\mathbf{4 d}$, respectively. The spectroscopic data of both complexes are similar.

The molecular structure of 7c has been confirmed by a single-crystal X-ray diffraction study. An ORTEP diagram is shown in Figure 2 , and selected bond distances and bond angles are given in Table 2. The metal center is coordinated to the $\mathrm{sp}^{2}$ carbon of the substituted pyrrole-2-thione ligand. The P1-Ru-P2, $\mathrm{P} 1-\mathrm{Ru}-\mathrm{C} 1$, and $\mathrm{P} 2-\mathrm{Ru}-\mathrm{Cl}$ angles are 83.75(4), 99.18(9), and $99.40(9)^{\circ}$, respectively. The $\mathrm{Ru}-\mathrm{C} 1$ distance of 2.094(3) $\AA$ is typical for a Ru-C single bond, and the $\mathrm{C} 1-\mathrm{C} 2$ distance of $1.368(4) \AA$ indicates a $\mathrm{C}-\mathrm{C}$ double bond. ${ }^{27}$ Two other $\mathrm{C}-\mathrm{C}$ bonds (1.522(4) $\AA$ for $\mathrm{C} 1-\mathrm{C} 4$ and 1.469 (4) $\AA$ for $C 2-C 3$ ) are slightly different but are still within the range of a single bond, as are the two $\mathrm{C}-\mathrm{N}$ bonds (1.479(4) $\AA$ for N1-C4 and 1.353(4) $\AA$ for $\mathrm{N} 1-\mathrm{C} 3)$. Of the analogous bonds (C1-C4 vs $\mathrm{C} 2-\mathrm{C} 3$ and $\mathrm{N} 1-\mathrm{C} 3$ vs N1-C4) in the five-membered ring the one closer to the metal center is generally slightly longer. 


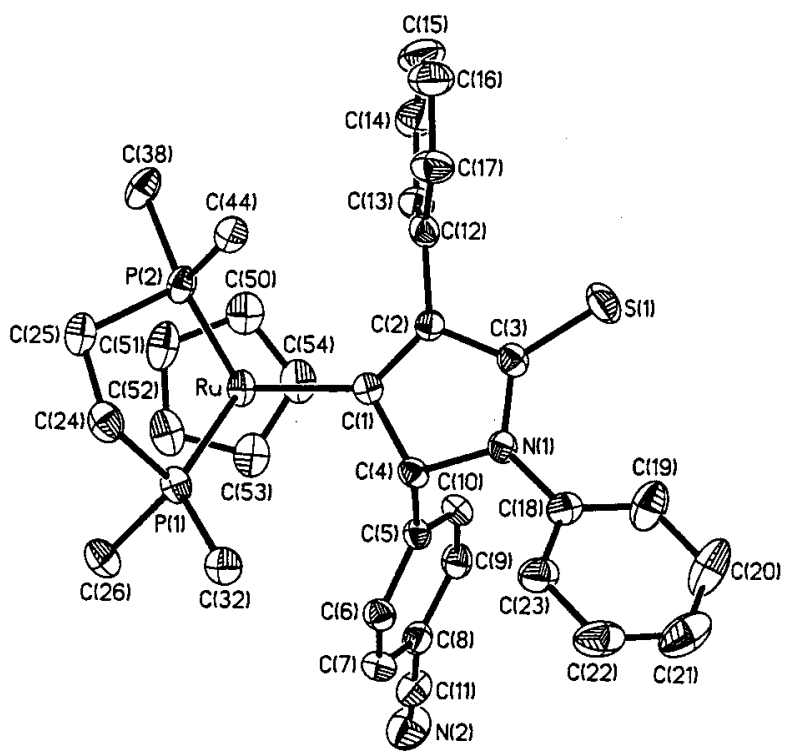

Figure 2. ORTEP drawing of 7c with thermal ellipsoids shown at the $30 \%$ probability level. For the dppe phenyl groups, only the ipso carbons are shown.

Table 2. Selected Bond Distances $(\AA)$ and Angles (deg) for

$\mathrm{Cp}(\mathrm{dppe}) \mathrm{Ru}-\mathrm{C}=\mathrm{C}(\mathrm{Ph}) \mathrm{C}(=\mathrm{S}) \mathrm{N}(\mathrm{Ph}) \mathrm{CH}\left(\mathrm{p}-\mathrm{C}_{6} \mathrm{H}_{4} \mathrm{CN}\right)$ (7c)

\begin{tabular}{llll}
\hline Ru-C1 & $2.094(3)$ & $\mathrm{C} 1-\mathrm{C} 2$ & $1.368(4)$ \\
$\mathrm{Ru}-\mathrm{P} 1$ & $2.3249(10)$ & $\mathrm{C} 1-\mathrm{C} 4$ & $1.522(4)$ \\
$\mathrm{Ru}-\mathrm{P} 2$ & $2.2840(10)$ & $\mathrm{C} 2-\mathrm{C} 3$ & $1.469(4)$ \\
$\mathrm{S} 1-\mathrm{C} 3$ & $1.664(3)$ & $\mathrm{C} 4-\mathrm{C} 5$ & $1.520(5)$ \\
$\mathrm{N} 1-\mathrm{C} 4$ & $1.479(4)$ & $\mathrm{N} 1-\mathrm{C} 18$ & $1.427(4)$ \\
$\mathrm{N} 1-\mathrm{C3}$ & $1.379(4)$ & $\mathrm{N} 2-\mathrm{C} 11$ & $1.144(5)$ \\
$\mathrm{P} 1-\mathrm{Ru}-\mathrm{P} 2$ & $83.75(4)$ & $\mathrm{C} 4-\mathrm{N} 1-\mathrm{C} 3$ & $109.9(3)$ \\
$\mathrm{P} 1-\mathrm{Ru}-\mathrm{C} 1$ & $99.18(9)$ & $\mathrm{S} 1-\mathrm{C} 3-\mathrm{C} 2$ & $126.7(3)$ \\
$\mathrm{P} 2-\mathrm{Ru}-\mathrm{C} 1$ & $99.40(9)$ & $\mathrm{C} 1-\mathrm{C} 2-\mathrm{C} 12$ & $130.2(3)$ \\
$\mathrm{Ru}-\mathrm{C} 1-\mathrm{C} 4$ & $121.1(2)$ & $\mathrm{C} 2-\mathrm{C} 3-\mathrm{S} 1$ & $126.7(3)$ \\
$\mathrm{Ru}-\mathrm{C} 1-\mathrm{C} 2$ & $132.8(2)$ & $\mathrm{S} 1-\mathrm{C} 3-\mathrm{N} 1$ & $125.6(3)$ \\
$\mathrm{C} 2-\mathrm{C} 1-\mathrm{C} 4$ & $105.7(3)$ & $\mathrm{C} 3-\mathrm{N} 1-\mathrm{C} 18$ & $127.8(3)$ \\
$\mathrm{C} 1-\mathrm{C} 4-\mathrm{N} 1$ & $105.0(2)$ & $\mathrm{C} 5-\mathrm{C} 4-\mathrm{N} 1$ & $110.4(3)$ \\
$\mathrm{C} 3-\mathrm{C} 2-\mathrm{C} 1$ & $111.4(3)$ & $\mathrm{C} 1-\mathrm{C} 4-\mathrm{C} 5$ & $114.0(3)$ \\
$\mathrm{C} 2-\mathrm{C} 3-\mathrm{N} 1$ & $107.8(3)$ & &
\end{tabular}

This has also been observed in ruthenium cyclopropenyl complexes. The bond distance of 1.664(3) A for C3-S1 is typical of a $\mathrm{C}-\mathrm{S}$ double bond. ${ }^{27}$

Concluding Remarks. Alkylations of the ruthenium complex $[\mathrm{Ru}]-\mathrm{C}=\mathrm{C}(\mathrm{Ph}) \mathrm{C}(=\mathrm{NPh}) \mathrm{S}$ with various organic halides $\mathrm{XCH}_{2} \mathrm{R}$ take place at both $\mathrm{S}$ and $\mathrm{N}$ atoms, affording vinylidene complexes $\mathbf{3}$ and $\mathbf{4}$, respectively. Deprotonation of these vinylidene complexes causes ring closure, yiel ding metal complexes containing heterocyclic ligands. Using this method, neutral 2-aminothiophene complexes $[\mathrm{Ru}]-\mathrm{C}=\mathrm{C}(\mathrm{R}) \mathrm{SC}(\mathrm{NHPh})=\mathrm{CPh}(\mathbf{6 a}, \mathrm{R}=\mathrm{CN}$; 6b, $\left.\mathrm{R}=\mathrm{CO}_{2} \mathrm{CH}_{3} ; \mathbf{6 c}, \mathrm{R}=\mathrm{p}-\mathrm{C}_{6} \mathrm{H}_{4} \mathrm{CN}\right)$ and pyrrole-2thione complexes $[\mathrm{Ru}]-\mathrm{C}=\mathrm{C}(\mathrm{Ph}) \mathrm{C}(=\mathrm{S}) \mathrm{N}(\mathrm{Ph}) \mathrm{CHR}(\mathbf{7 c}$, $\mathrm{R}=\mathrm{p}-\mathrm{C}_{6} \mathrm{H}_{4} \mathrm{CN} ; \mathbf{7 d}, \mathrm{R}=\mathrm{Ph}$ ) are all obtainable in moderate to high yield. We are currently investigating possible asymmetric induction by using the chiral ruthenium metal center with different phosphine ligands.

\section{Experimental Section}

General Procedures. All manipulations were performed under nitrogen using vacuum-line, drybox, and standard
Schlenk techniques. $\mathrm{CH}_{2} \mathrm{Cl}_{2}$ was distilled from $\mathrm{CaH}_{2}$, and diethyl ether and THF were distilled from sodium diphenylketyl. All other solvents and reagents were of reagent grade and were used as received. NMR spectra were recorded on Bruker AC-200 and AM-300WB FT-NMR spectrometers at room temperature (unless states otherwise) and are reported in units of $\delta$ with residual protons in the solvents as a standard $\left(\mathrm{CDCl}_{3}, \delta 7.24 ; \mathrm{C}_{2} \mathrm{D}_{6} \mathrm{O}, \delta\right.$ 2.04). $\mathrm{FAB}$ mass spectra were recorded on a J EOL SX-102A spectrometer. The complexes $[\mathrm{Ru}] \mathrm{C} \equiv \mathrm{CPh}\left(\mathbf{1},[\mathrm{Ru}]=\left(\eta^{5}-\mathrm{C}_{5} \mathrm{H}_{5}\right)(\mathrm{dppe}) \mathrm{Ru}, \mathrm{dppe}=\mathrm{Ph}_{2} \mathrm{PCH}_{2^{-}}\right.$ $\left.\mathrm{CH}_{2} \mathrm{PPh}_{2}\right)$ and $[\mathrm{Ru}]-\mathrm{C}=\mathrm{C}(\mathrm{Ph}) \mathrm{C}(=\mathrm{NPh}) \mathrm{S}$ (2) were prepared according to the methods reported in the literature. ${ }^{16}$ Elemental analyses and X-ray diffraction studies were carried out at the Regional Center of Analytical Instrument located at the National Taiwan University.

Synthesis of $\left\{[\mathbf{R u}]=\mathbf{C}=\mathbf{C}(\mathbf{P h}) \mathbf{S}(=\mathbf{N P h}) \mathbf{C H}_{2} \mathbf{C N}\right\}[\mathbf{I}]$ (3a). To a $\mathrm{CH}_{2} \mathrm{Cl}_{2}(20.0 \mathrm{~mL})$ solution of $\mathbf{2}(200 \mathrm{mg}, 0.250 \mathrm{mmol})$ was added $\mathrm{ICH}_{2} \mathrm{CN}(0.10 \mathrm{~mL}, 0.75 \mathrm{mmol})$ under nitrogen. The resulting solution was stirred at room temperature for $2 \mathrm{~h}$; then the solvent was reduced to $5 \mathrm{~mL}$. This mixture was slowly added to $60 \mathrm{~mL}$ of vigorously stirred diethyl ether. The purple red precipitate thus formed was filtered and washed with diethyl ether and hexane and dried under vacuum to give $\left\{[\mathrm{Ru}]=\mathrm{C}=\mathrm{C}(\mathrm{Ph}) \mathrm{C}(=\mathrm{NPh}) \mathrm{SCH}_{2} \mathrm{CN}\right\}[\mathrm{I}] \quad$ (3a; $214.7 \mathrm{mg}, 0.222$ $\mathrm{mmol}$ ) in $89 \%$ yield. Spectroscopic data for $3 \mathrm{a}$ : ${ }^{1} \mathrm{H}$ NMR $\left(\mathrm{CDCl}_{3}\right) \delta 7.63-6.32(\mathrm{~m}, 30 \mathrm{H}, \mathrm{Ph}), 5.44(\mathrm{~s}, 5 \mathrm{H}, \mathrm{Cp}), 3.53(\mathrm{~s}$, $\left.2 \mathrm{H}, \mathrm{CH}_{2}\right), 3.50-3.00\left(\mathrm{~m}, 4 \mathrm{H}, \mathrm{CH}_{2}\right) ;{ }^{31} \mathrm{P} \mathrm{NMR}\left(\mathrm{CDCl}_{3}\right) \delta 77.55$; ${ }^{13} \mathrm{C} \mathrm{NMR}\left(\mathrm{CDCl}_{3}\right) \delta 340.7\left(\mathrm{t}, \mathrm{C}_{\alpha}\right.$, J c-p $\left.=13.40 \mathrm{~Hz}\right), 148.6(\mathrm{~s}$, SCN), 132.7-120.6 (Ph and $\left.\mathrm{C}_{\beta}\right), 117.9(\mathrm{CN}), 93.2(\mathrm{Cp}), 28.1$ (t, $\mathrm{PCH}_{2}$, J c-p $\left.=25.6 \mathrm{~Hz}\right), 17.4\left(\mathrm{~s}, \mathrm{CH}_{2}\right) ; \mathrm{MS}\left(\mathrm{m} / \mathrm{z}, \mathrm{Ru}^{102}\right) 841.1$ $\left(\mathrm{M}^{+}-\mathrm{I}\right), 565.0\left(\mathrm{M}^{+}-\mathrm{CCPh}-\mathrm{PhNCS}-\mathrm{CH}_{2} \mathrm{CN}\right)$. Anal. Calcd for $\mathrm{C}_{48} \mathrm{H}_{41} \mathrm{~N}_{2} \mathrm{P}_{2} \mathrm{SRul}$ (967.80): C, 59.57; $\mathrm{H}, 4.27 ; \mathrm{N}, 2.89$. Found: C, 59.23; H, 4.58; N, 3.12.

Synthesis of $\left\{[\mathrm{Ru}]=\mathrm{C}=\mathrm{C}(\mathrm{Ph}) \mathrm{C}(=\mathrm{NPh}) \mathrm{SCH}_{2} \mathrm{CO}_{2} \mathrm{CH}_{3}\right\}-$ [Br] (3b) and $\left\{[\mathrm{Ru}]=\mathrm{C}=\mathrm{C}(\mathrm{Ph}) \mathrm{C}(=\mathrm{S}) \mathbf{N}(\mathrm{Ph}) \mathrm{CH}_{2} \mathrm{CO}_{2} \mathrm{CH}_{3}\right\}$ [Br] (4b). To a $\mathrm{CH}_{2} \mathrm{Cl}_{2}$ solution (20 mL) of $\mathbf{2}(200 \mathrm{mg}, 0.250$ $\mathrm{mmol}$ ) was added $\mathrm{BrCH}_{2} \mathrm{CO}_{2} \mathrm{CH}_{3}(0.1 \mathrm{~mL}, 0.75 \mathrm{mmol})$. The resulting solution was stirred at room temperature for $3 \mathrm{~h}$. ${ }^{1} \mathrm{H}$ and ${ }^{31} \mathrm{P}$ NMR spectra of the mixture indicated formation of the two major products $\mathbf{3 b}$ and $\mathbf{4 b}$. Then the solvent was reduced to $5 \mathrm{~mL}$. This mixture was slowly added to $60 \mathrm{~mL}$ of vigorously stirred diethyl ether. The purple-red precipitate was filtered off, washed with diethyl ether and hexane, and dried under vacuum to give a mixture of $\mathbf{3 b}$ and $\mathbf{4 b}(190.6 \mathrm{mg}, 0.200$ $\mathrm{mmol}$ ) in a total yield of $80 \%$. The ${ }^{31} \mathrm{P}$ NMR spectrum of the mixture displayed resonances attributed to $\mathbf{3 b}$ and $\mathbf{4 b}$ in a $\mathbf{3 : 2}$ ratio. Spectroscopic data for 3b: ${ }^{1} \mathrm{H}$ NMR $\left(\mathrm{CDCl}_{3}\right) \delta 7.58-6.76$ $(\mathrm{m}, 30 \mathrm{H}, \mathrm{Ph}), 5.52(\mathrm{~s}, 5 \mathrm{H}, \mathrm{Cp}), 3.68\left(\mathrm{~s}, 3 \mathrm{H}, \mathrm{OCH}_{3}\right), 3.45(\mathrm{~s}, 2 \mathrm{H}$, $\left.\mathrm{CH}_{2}\right), 3.00-2.65\left(\mathrm{~m}, 4 \mathrm{H}, \mathrm{PCH}_{2} \mathrm{CH}_{2} \mathrm{P}\right)$; ${ }^{31} \mathrm{P} \mathrm{NMR}\left(\mathrm{CDCl}_{3}\right) \delta$ 77.23; ${ }^{13} \mathrm{C}$ NMR $\left(\mathrm{CDCl}_{3}\right) \delta 341.5\left(\mathrm{t}, \mathrm{C}_{\alpha}, \mathrm{J} \mathrm{C}-\mathrm{P}=18.2 \mathrm{~Hz}\right), 169.5$ (CO), $145.6(\mathrm{SCN}), 141.9-121.6\left(\mathrm{Ph}\right.$ and $\mathrm{C}_{\beta}$ ), $94.5(\mathrm{Cp}), 53.7$ $\left(\mathrm{OCH}_{3}\right), 35.7\left(\mathrm{CH}_{2}\right), 28.4\left(\mathrm{t}, \mathrm{PCH}_{2}, \mathrm{~J} \mathrm{C}-\mathrm{P}=23.2 \mathrm{~Hz}\right) ; \mathrm{MS}(\mathrm{m} / \mathrm{z}$, $\left.\mathrm{Ru}^{102}\right)$ 874.1 ( $\left.\mathrm{M}^{+}-\mathrm{Br}\right), 565.0\left(\mathrm{M}^{+}-\mathrm{CCPh}-\mathrm{PhNCS}-\mathrm{CH}_{2^{-}}\right.$ $\left.\mathrm{CO}_{2} \mathrm{CH}_{3}\right)$. Spectroscopic data for $\mathbf{4 b}$ : ${ }^{1} \mathrm{H} \mathrm{NMR}\left(\mathrm{CDCl}_{3}\right) 7.54-$ $6.35(\mathrm{~m}, 3 \mathrm{OH}, \mathrm{Ph}), 5.48(\mathrm{~s}, 5 \mathrm{H}, \mathrm{Cp}), 3.59\left(\mathrm{~s}, 3 \mathrm{H}, \mathrm{OCH}_{3}\right), 3.43$ $\left(\mathrm{s}, 2 \mathrm{H}, \mathrm{CH}_{2}\right), 2.80-2.35\left(\mathrm{~m}, 4 \mathrm{H}, \mathrm{PCH}_{2} \mathrm{CH}_{2} \mathrm{P}\right) ;{ }^{31} \mathrm{P} \mathrm{NMR}\left(\mathrm{CDCl}_{3}\right)$ $\delta 79.02 ;{ }^{13} \mathrm{C}$ NMR $\left(\mathrm{CDCl}_{3}\right) 342.2\left(\mathrm{t}, \mathrm{C}_{\alpha}, \mathrm{J} \mathrm{C}_{-\mathrm{P}}=17.7 \mathrm{~Hz}\right), 183.4$ (CS), 168.1 (CO), 145.0-120.5 (Ph and $\mathrm{C}_{\beta}$ ), $93.3(\mathrm{Cp}), 36.9$ $\left(\mathrm{CH}_{2}\right), 30.3\left(\mathrm{t}, \mathrm{PCH}_{2}\right.$, J $\left.\mathrm{c}-\mathrm{p}=22.1 \mathrm{~Hz}\right) ; \mathrm{MS}\left(\mathrm{m} / \mathrm{z}, \mathrm{Ru}^{102}\right) 847.1$ $\left(\mathrm{M}^{+}-\mathrm{Br}\right), 565.0\left(\mathrm{M}^{+}-\mathrm{CCPh}-\mathrm{PhNCS}-\mathrm{CH}_{2} \mathrm{CO}_{2} \mathrm{CH}_{3}\right)$. Anal. Calcd for $\mathrm{C}_{49} \mathrm{H}_{44} \mathrm{NO}_{2} \mathrm{P}_{2} \mathrm{SRuBr}$ (953.83): C, 61.70; $\mathrm{H}, 4.65 ; \mathrm{N}$, 1.47. Found for the mixture of $\mathbf{3 b}$ and $\mathbf{4 b}$ : $\mathbf{C}, 60.93 ; \mathbf{H}, 4.55$; N, 1.32 .

Mixtures of the complexes $\left\{[\mathrm{Ru}]=\mathrm{C}=\mathrm{C}(\mathrm{Ph}) \mathrm{C}(=\mathrm{NPh}) \mathrm{SCH}_{2^{-}}\right.$ $\left.\left(\mathrm{p}-\mathrm{C}_{6} \mathrm{H}_{4} \mathrm{CN}\right)\right\}[\mathrm{Br}](3 \mathrm{c})$ and $\left\{[\mathrm{Ru}]=\mathrm{C}=\mathrm{C}(\mathrm{Ph}) \mathrm{C}(=\mathrm{S}) \mathrm{N}(\mathrm{Ph}) \mathrm{CH}_{2}(\mathrm{p}-\right.$ $\left.\left.\mathrm{C}_{6} \mathrm{H}_{4} \mathrm{CN}\right)\right\}[\mathrm{Br}](\mathbf{4 c})(\mathbf{3 c}: \mathbf{4 c}=1: 2,87 \%$ total yield) as well as $\left\{[\mathrm{Ru}]=\mathrm{C}=\mathrm{C}(\mathrm{Ph}) \mathrm{C}(=\mathrm{NPh}) \mathrm{SCH}_{2} \mathrm{Ph}\right\}[\mathrm{Br}]$ (3d) and $\{[\mathrm{Ru}]=\mathrm{C}=$ $\left.\mathrm{C}(\mathrm{Ph})-\mathrm{C}(=\mathrm{S}) \mathrm{N}(\mathrm{Ph}) \mathrm{CH}_{2} \mathrm{Ph}\right\}[\mathrm{Br}](\mathbf{4 d})(\mathbf{3 d}: \mathbf{4 d}=6: 5,83 \%$ total yield) were prepared using the same procedure as that for $\mathbf{3 b}$ and $\mathbf{4 b}$. Spectroscopic data for $3 \mathbf{c}:{ }^{1} \mathrm{H}$ NMR $\left(\mathrm{CDCl}_{3}\right) \delta 7.60-$ 
$6.18(\mathrm{~m}, 34 \mathrm{H}, \mathrm{Ph}), 5.39$ (s, 5H, Cp), $3.33\left(\mathrm{~s}, 2 \mathrm{H}, \mathrm{CH}_{2}\right), 3.20$ $2.60\left(\mathrm{~m}, 4 \mathrm{H}, \mathrm{PCH}_{2} \mathrm{CH}_{2} \mathrm{P}\right) ;{ }^{31} \mathrm{P} \mathrm{NMR}\left(\mathrm{CDCl}_{3}\right) \delta 77.98 ;{ }^{13} \mathrm{C} \mathrm{NMR}$ $\left(\mathrm{CDCl}_{3}\right) \delta 354.7\left(\mathrm{t}, \mathrm{C}_{\alpha}, \mathrm{J} \mathrm{C}-\mathrm{P}=12.1 \mathrm{~Hz}\right), 182.5(\mathrm{~s}, \mathrm{SCN}), 140.4-$ $126.6\left(\mathrm{Ph}\right.$ and $\left.\mathrm{C}_{\beta}\right)$, $111.6(\mathrm{CN}), 93.6(\mathrm{Cp}), 30.9\left(\mathrm{CH}_{2}\right), 28.1$ (t, $\mathrm{PCH}_{2}$, J $\left.\mathrm{C}-\mathrm{P}=23.7 \mathrm{~Hz}\right)$; $\mathrm{MS}\left(\mathrm{m} / \mathrm{z}, \mathrm{Ru}^{102}\right) 917.2\left(\mathrm{M}^{+}-\mathrm{Br}\right), 565.1$ $\left(\mathrm{M}^{+}-\mathrm{CCPh}-\mathrm{PhNCS}-\mathrm{CH}_{2} \mathrm{C}_{6} \mathrm{H}_{4} \mathrm{CN}\right)$. Spectroscopic data for 4c: ${ }^{1} \mathrm{H}$ NMR $\left(\mathrm{CDCl}_{3}\right) \delta 7.59-6.08(\mathrm{~m}, 34 \mathrm{H}, \mathrm{Ph}), 5.44(\mathrm{~s}, 5 \mathrm{H}$, $\mathrm{Cp}), 3.38\left(\mathrm{~s}, 2 \mathrm{H}, \mathrm{CH}_{2}\right), 3.40-2.80\left(\mathrm{~m}, 4 \mathrm{H}, \mathrm{PCH}_{2} \mathrm{CH}_{2} \mathrm{P}\right)$; ${ }^{31} \mathrm{P}$ NMR $\left(\mathrm{CDCl}_{3}\right) \delta 79.51 ;{ }^{13} \mathrm{C} \mathrm{NMR}\left(\mathrm{CDCl}_{3}\right): \delta 354.0\left(\mathrm{t}, \mathrm{C}_{\alpha}, \mathrm{J} \mathrm{C}-\mathrm{P}\right.$ $=15.2 \mathrm{~Hz}$ ), $218.2(\mathrm{~s}, \mathrm{CS}), 135.8-126.4\left(\mathrm{Ph}\right.$ and $\left.\mathrm{C}_{\beta}\right), 92.5(\mathrm{Cp})$, $31.4\left(\mathrm{CH}_{2}\right), 27.7\left(\mathrm{t}, \mathrm{PCH}_{2}, \mathrm{~J}_{\mathrm{C}-\mathrm{P}}=23.2 \mathrm{~Hz}\right) ; \mathrm{MS}\left(\mathrm{m} / \mathrm{z}, \mathrm{Ru}^{102}\right)$ $917.2\left(\mathrm{M}^{+}-\mathrm{Br}\right), 565.1\left(\mathrm{M}^{+}-\mathrm{CCPh}-\mathrm{PhNCS}-\mathrm{CH}_{2} \mathrm{C}_{6} \mathrm{H}_{4^{-}}\right.$ $\mathrm{CN}$ ). Anal. Calcd for $\mathrm{C}_{54} \mathrm{H}_{45} \mathrm{~N}_{2} \mathrm{P}_{2} \mathrm{SRuBr}$ (996.89): C, 65.06; $\mathrm{H}$, 4.55; N, 2.81. Found for the mixture of $3 \mathrm{c}$ and $4 \mathrm{c}$ : C, 64.92; $\mathrm{H}, 4.46 ; \mathrm{N}, 2.72$. Spectroscopic data for 3d: ${ }^{1} \mathrm{H} \mathrm{NMR}\left(\mathrm{CDCl}_{3}\right)$ $\delta$ 7.75-6.25 (m, 35H, Ph), $5.40(\mathrm{~s}, 5 \mathrm{H}, \mathrm{Cp}), 4.46\left(\mathrm{~s}, 2 \mathrm{H}, \mathrm{CH}_{2}\right)$, 3.10-3.40 (m, 4H, $\left.\mathrm{PCH}_{2} \mathrm{CH}_{2} \mathrm{P}\right) ;{ }^{1} \mathrm{P} \mathrm{NMR}\left(\mathrm{CDCl}_{3}\right) \delta 78.12 ;{ }^{13} \mathrm{C}$ NMR $\left(\mathrm{CDCl}_{3}\right) \delta 184.0(\mathrm{~s}, \mathrm{SCN}), 145.3-121.2\left(\mathrm{Ph}\right.$ and $\left.\mathrm{C}_{\beta}\right), 93.7$ (Cp), $28.9\left(\mathrm{t}, \mathrm{PCH}_{2}\right.$, J c-p $\left.=21.9 \mathrm{~Hz}\right), 15.9\left(\mathrm{CH}_{2}\right)$; $\mathrm{MS}\left(\mathrm{m} / \mathrm{z}, \mathrm{Ru}^{102}\right)$ $892.3\left(\mathrm{M}^{+}-\mathrm{Br}\right), 565.1\left(\mathrm{M}^{+}-\mathrm{CCPh}-\mathrm{PhNCS}-\mathrm{CH}_{2} \mathrm{C}_{6} \mathrm{H}_{5}\right)$. Spectroscopic data for $\mathbf{4 d}$ : ${ }^{1} \mathrm{H}$ NMR $\left(\mathrm{CDCl}_{3}\right) \delta 7.59-6.06(\mathrm{~m}$, $35 \mathrm{H}, \mathrm{Ph}), 5.33(\mathrm{~s}, 5 \mathrm{H}, \mathrm{Cp}), 3.30\left(\mathrm{~s}, 2 \mathrm{H}, \mathrm{CH}_{2}\right), 3.10-3.40(\mathrm{~m}$, $\left.4 \mathrm{H}, \mathrm{PCH}_{2} \mathrm{CH}_{2} \mathrm{P}\right) ;{ }^{31} \mathrm{P} \mathrm{NMR}\left(\mathrm{CDCl}_{3}\right) \delta 81.11 ;{ }^{13} \mathrm{C} \mathrm{NMR}\left(\mathrm{CDCl}_{3}\right)$ $\delta 207.4$ (s, CS), 143.1-120.3 (Ph and $\mathrm{C}_{\beta}$ ), $92.8(\mathrm{Cp}), 29.2(\mathrm{t}$, $\mathrm{PCH}_{2}$, J $\left.\mathrm{C}-\mathrm{P}=23.4 \mathrm{~Hz}\right), 14.7\left(\mathrm{CH}_{2}\right) ; \mathrm{MS}\left(\mathrm{m} / \mathrm{z}, \mathrm{Ru}^{102}\right) 892.3\left(\mathrm{M}^{+}\right.$ $-\mathrm{Br}), 565.1\left(\mathrm{M}^{+}-\mathrm{CCPh}-\mathrm{PhNCS}-\mathrm{CH}_{2} \mathrm{C}_{6} \mathrm{H}_{5}\right)$. Anal. Calcd for $\mathrm{C}_{53} \mathrm{H}_{46} \mathrm{NP}_{2} \mathrm{SRuBr}$ (971.88): C, 65.49; $\mathrm{H}, 4.77 ; \mathrm{N}, 1.44$. Found for the mixture of $\mathbf{3 d}$ and $\mathbf{4 d}$ : C, 65.74; H, 4.75; N, 1.51 .

Synthesis of $[R u]-C=C(C N) S C(N H P h)=C P h(6 a)$. To a solution of $3 \mathbf{a}$ (300 $\mathrm{mg}, 0.310 \mathrm{mmol}$ ) in $15 \mathrm{~mL}$ of acetone was added $\mathrm{n}-\mathrm{Bu}_{4} \mathrm{NOH}(1 \mathrm{~mL}, 1 \mathrm{M}$ in $\mathrm{MeOH})$. The mixture was stirred at room temperature for 30 min to give a bright yellow solution, and then the solvent was reduced to $3.0 \mathrm{~mL}$. The residue was chromatographed on a alumina column. The yellow product was eluted with benzene. The solvent of the eluate was reduced to ca. $1 \mathrm{~mL}$, and $15 \mathrm{~mL}$ of hexane was added to give yellow precipitates. The solid product was filtered and washed with $10 \mathrm{~mL}$ of hexane to give $[\mathrm{Ru}]-C=\mathrm{C}(\mathrm{CN}) \mathrm{SC}$ $(\mathrm{NHPh})=\mathrm{CPh}(6 \mathbf{6} ; 177.0 \mathrm{mg}, 0.211 \mathrm{mmol})$ in $68 \%$ yield. Spectroscopic data for $6 \mathbf{6}:{ }^{1} \mathrm{H}$ NMR $\left(\mathrm{CDCl}_{3}\right) \delta 7.34-6.41(\mathrm{~m}$, $30 \mathrm{H}, \mathrm{Ph}), 5.47(\mathrm{~s}, \mathrm{NH}), 3.92(\mathrm{~s}, 5 \mathrm{H}, \mathrm{Cp}), 2.13,1.68(2 \mathrm{~m}, 4 \mathrm{H}$, $\left.\mathrm{CH}_{2}\right) ; 31 \mathrm{P} \mathrm{NMR}\left(\mathrm{CDCl}_{3}\right) \delta 67.55(\mathrm{br}) ; 31 \mathrm{P} \mathrm{NMR}$ (acetone at -80 $\left.{ }^{\circ} \mathrm{C}\right) \delta 71.76,60.79(2 \mathrm{~d}$, J p-p $=32.6 \mathrm{~Hz}) ;{ }^{13} \mathrm{C} \mathrm{NMR}\left(\mathrm{CDCl}_{3}\right) \delta$ 171.8 (s, SCN), 141.5-120.8 (Ph and $\left.\mathrm{C}_{\alpha}, \mathrm{C}_{\beta}\right), 116.1(\mathrm{CN}), 84.2$ $(\mathrm{Cp})$, 33.7, $33.3(2 \mathrm{t}, \mathrm{PCH} 2$, J $\mathrm{c}-\mathrm{p}=22.6 \mathrm{~Hz}) ; \mathrm{MS}\left(\mathrm{m} / \mathrm{z}, \mathrm{Ru}^{102}\right)$ $840.0\left(\mathrm{M}^{+}\right), 565.0\left(\mathrm{M}^{+}-\mathrm{CCPh}-\mathrm{PhNCS}-\mathrm{CHCN}\right)$. Anal. Calcd for $\mathrm{C}_{48} \mathrm{H}_{40} \mathrm{~N}_{2} \mathrm{P}_{2} \mathrm{SRu}$ (839.89): C, 68.64; $\mathrm{H}, 4.80 ; \mathrm{N}, 3.34$. Found: $\mathrm{C}, 69.02 ; \mathrm{H}, 4.58 ; \mathrm{N}, 3.27$. The intermediate [Ru]-

$\mathrm{C}=\mathrm{C}(\mathrm{Ph}) \mathrm{S}(=\mathrm{NPh}) \mathrm{CHCN}(\mathbf{5 a})$ was observed in about $10 \mathrm{~min}$ when the reaction was monitored by NMR spectroscopy. Complex $\mathbf{5 a}$ is unstable and readily converted to $\mathbf{6 a}$ when passed through an alumina column at room temperature. Spectroscopic data for $5 \mathrm{a}:{ }^{1} \mathrm{H}$ NMR $\left(\mathrm{CDCl}_{3}\right) \delta 7.81-6.28(\mathrm{~m}$, $30 \mathrm{H}, \mathrm{Ph}), 4.65(\mathrm{~s}, \mathrm{H}, \mathrm{CHCN}), 4.17(\mathrm{~s}, 5 \mathrm{H}, \mathrm{Cp}), 2.32,2.08(2 \mathrm{~m}$, $\left.4 \mathrm{H}, \mathrm{CH}_{2}\right) ;{ }^{31} \mathrm{P} \mathrm{NMR}\left(\mathrm{CDCl}_{3}\right) \delta 72.30,69.12(2 \mathrm{~d}, \mathrm{~J}$ p-p $=29.8$ $\mathrm{Hz})$; MS (m/z, Ru $\left.{ }^{102}\right) 840.0\left(\mathrm{M}^{+}\right), 565.0\left(\mathrm{M}^{+}-\mathrm{CCPh}-\mathrm{PhNCS}\right.$ $-\mathrm{CHCN}$ ).

Complex $\mathbf{5 b}$ ( $48 \%$ based on $\mathbf{3 b}$ ) was similarly prepared from the reaction of $n-\mathrm{Bu}_{4} \mathrm{NOH}$ with a mixture of $\mathbf{3 b}$ and $\mathbf{4 b}$. In this reaction $\mathbf{4} \mathbf{b}$ decomposed to give $\mathbf{2}$. The products $\mathbf{5 b}$ and $\mathbf{2}$ were separated by column chromatography. When it was dissolved in solution, complex $\mathbf{5 b}$ transformed to $\mathbf{6} \mathbf{b}$ in ca. $\mathbf{9 5 \%}$ yield. Spectroscopic data for $\mathbf{5 b}$ : ${ }^{1} \mathrm{H}$ NMR $\left(\mathrm{CDCl}_{3}\right) \delta 7.82$ $6.34(\mathrm{~m}, 30 \mathrm{H}, \mathrm{Ph}), 4.01(\mathrm{~s}, 5 \mathrm{H}, \mathrm{Cp}), 3.82(\mathrm{~s}, 1 \mathrm{H}, \mathrm{CH}), 3.27(\mathrm{~s}$ $\left.3 \mathrm{H}, \mathrm{OCH}_{3}\right), 2.65-2.50\left(2 \mathrm{~m}, 4 \mathrm{H}, \mathrm{PCH}_{2} \mathrm{CH}_{2} \mathrm{P}\right)$; $31 \mathrm{P} \mathrm{NMR}\left(\mathrm{CDCl}_{3}\right)$ $\delta 71.03,69.98(2 \mathrm{~d}$, J $\mathrm{p}-\mathrm{p}=30.68 \mathrm{~Hz}) ; \mathrm{MS}\left(\mathrm{m} / \mathrm{z}, \mathrm{Ru}^{102}\right) 873.0$ $\left(\mathrm{M}^{+}\right), 565.0\left(\mathrm{M}^{+}-\mathrm{CCPh}-\mathrm{PhNCS}-\mathrm{CHCO}_{2} \mathrm{CH}_{3}\right)$. Spectroscopic data for $\mathbf{6 b}$ : ${ }^{1} \mathrm{H}$ NMR $\left(\mathrm{CDCl}_{3}\right) \delta 7.71-6.38(\mathrm{~m}, 30 \mathrm{H}, \mathrm{Ph})$, $5.46(\mathrm{~s}, 1 \mathrm{H}, \mathrm{NH}), 3.92(\mathrm{~s}, 5 \mathrm{H}, \mathrm{Cp}), 3.07\left(\mathrm{~s}, 3 \mathrm{H}, \mathrm{OCH}_{3}\right), 2.02$, $1.66\left(2 \mathrm{~m}, 4 \mathrm{H}, \mathrm{PCH}_{2} \mathrm{CH}_{2} \mathrm{P}\right) ;{ }^{31 \mathrm{P}} \mathrm{NMR}\left(-40{ }^{\circ} \mathrm{C}, \mathrm{CDCl}_{3}\right) \delta 69.73$, $58.66(2 \mathrm{~d}, \mathrm{~J} p-\mathrm{p}=32.2 \mathrm{~Hz}) ;{ }^{13} \mathrm{C} \mathrm{NMR}\left(\mathrm{CDCl}_{3}\right) \delta 178.6(\mathrm{CO})$, 165.4 (s, SCN), 143.2-116.3 ( $\mathrm{Ph}$ and $\mathrm{C}_{\alpha}, \mathrm{C}_{\beta}$ ), $84.5(\mathrm{Cp}), 50.0$ $\left(\mathrm{CH}_{3}\right), 35.4\left(\mathrm{t}, \mathrm{PCH}_{2}, \mathrm{~J} \mathrm{C}_{\mathrm{P}}=18.2 \mathrm{~Hz}\right), 37.1$ (t, $\mathrm{PCH}_{2}$, J $\mathrm{c}-\mathrm{p}=$ $20.1 \mathrm{~Hz}), 15.8(\mathrm{~s}, \mathrm{CH})$; MS (m/z, Ru $\left.\mathrm{Ru}^{102}\right) 873.0\left(\mathrm{M}^{+}\right), 565.0\left(\mathrm{M}^{+}\right.$ - $\mathrm{CCPh}-\mathrm{PhNCS}-\mathrm{CHCO}_{2} \mathrm{CH}_{3}$ ). Anal. Calcd for $\mathrm{C}_{49} \mathrm{H}_{43}$ $\mathrm{NO}_{2} \mathrm{P}_{2} \mathrm{SRu}$ (872.92): C, 67.20; $\mathrm{H}, 4.91 ; \mathrm{N}, 1.60$. Found: C, $66.85 ; \mathrm{H}, 4.92 ; \mathrm{N}, 1.61$.

\section{Synthesis of $[R u]-C=C(P h) C(=N P h) S C H\left(p-C_{6} H_{4} C N\right)$}

\section{(5c) and [Ru] $-\mathrm{C}=\mathrm{C}(\mathrm{Ph})-\mathrm{C}(=\mathrm{S}) \mathrm{N}(\mathrm{Ph}) \mathrm{CH}\left(\mathrm{p}-\mathrm{C}_{6} \mathrm{H}_{4} \mathrm{CN}\right)(7 \mathrm{c})$.} To a mixture of $\mathbf{3 c}$ and $\mathbf{4 c}(300 \mathrm{mg}, 0.301 \mathrm{mmol}, \mathbf{3 c}: \mathbf{4 c}=1: 2)$ in $15 \mathrm{~mL}$ of acetone was added $\mathrm{n}-\mathrm{Bu}_{4} \mathrm{NOH}(1 \mathrm{~mL}, 1 \mathrm{M}$ in $\mathrm{MeOH}$ ). The mixture was stirred at room temperature for 30 min to give a bright yellow solution, and then the volume of the solution was reduced to ca. $3 \mathrm{~mL}$. The residue was then chromatographed on an al umina column. Diethyl ether eluted compound $\mathbf{7 c}$, and acetone el uted compound $\mathbf{5 c}$. Removal of the diethyl ether under vacuum give the solid product $7 \mathrm{c}$ (119.4 mg, $0.130 \mathrm{mmol}$ ) in 65\% yield (based on 4c). Removal of the acetone gave an oily residue which was washed with 2

$\times 10 \mathrm{~mL}$ of hexanetogive $[\mathrm{Ru}] \mathrm{C}=\mathrm{C}(\mathrm{Ph}) \mathrm{C}(=\mathrm{NPh}) \mathrm{SCH}\left(\mathrm{p}-\mathrm{C}_{6} \mathrm{H}_{4^{-}}\right.$ $\mathrm{CN})(\mathbf{5 c} ; 68.9 \mathrm{mg}, 0.075 \mathrm{mmol}$ ) in $75 \%$ yield based on $3 \mathbf{c}$.

Complex $\mathbf{5 c}$ in solution transformed to $[\mathrm{Ru}] \mathrm{C}=\mathrm{C}\left(\mathrm{p}-\mathrm{C}_{6} \mathrm{H}_{4} \mathrm{CN}\right)$ -

$\mathrm{SC}(\mathrm{NHPh})=\mathrm{CPh}(\mathbf{6 c})$ in $36 \mathrm{~h}$ at room temperature quantitatively. Spectroscopic data for $\mathbf{5 c}$ : ${ }^{1} \mathrm{H}$ NMR $\left(\mathrm{CDCl}_{3}\right) \delta 7.50-$ $6.04(\mathrm{~m}, 34 \mathrm{H}, \mathrm{Ph}), 3.77(\mathrm{~s}, 5 \mathrm{H}, \mathrm{Cp}), 3.58(\mathrm{~s}, \mathrm{CH}), 2.85-2.50$ $\left(\mathrm{m}, 4 \mathrm{H}, \mathrm{PCH}_{2} \mathrm{CH}_{2} \mathrm{P}\right) ;{ }^{31} \mathrm{P} \mathrm{NMR}\left(\mathrm{CDCl}_{3}\right) \delta 69.31,67.54(2 \mathrm{~d}, \mathrm{~J}$ P-P $=30.85 \mathrm{~Hz}) ;{ }^{13} \mathrm{C} \mathrm{NMR}\left(\mathrm{CDCl}_{3}\right) \delta 162.7(\mathrm{~s}, \mathrm{SCN}), 142.6-120.7$ $\left(\mathrm{Ph}\right.$ and $\mathrm{C}_{\alpha}, \mathrm{C}_{\beta}$ ), $112.0(\mathrm{CN}), 84.2(\mathrm{Cp}), 30.3,30.0$ (2t, $\mathrm{PCH}_{2-}$ $\left.\mathrm{CH}_{2} \mathrm{P}, \mathrm{J}_{\mathrm{c}-\mathrm{P}}=11.0 \mathrm{~Hz}\right), 28.3(\mathrm{~s}, \mathrm{CH}) ; \mathrm{MS}\left(\mathrm{m} / \mathrm{z}, \mathrm{Ru}^{102}\right) 916.2$ $\left(\mathrm{M}^{+}\right), 565.1\left(\mathrm{M}^{+}-\mathrm{CCPh}-\mathrm{PhNCS}-\mathrm{CHC}_{6} \mathrm{H}_{4} \mathrm{CN}\right)$. Spectroscopic data for $6 \mathrm{c}:{ }^{1} \mathrm{H}$ NMR $\left(\mathrm{CDCl}_{3}\right) \delta 7.43-6.35(\mathrm{~m}, 34 \mathrm{H}, \mathrm{Ph})$, $5.84(\mathrm{~s}, \mathrm{NH}), 3.49(\mathrm{~s}, 5 \mathrm{H}, \mathrm{Cp}), 2.45-2.00\left(\mathrm{~m}, 4 \mathrm{H}, \mathrm{PCH}_{2} \mathrm{CH}_{2} \mathrm{P}\right)$; ${ }^{31} \mathrm{P}$ NMR $\left(\mathrm{CDCl}_{3}\right) \delta 72.15,66.40(2 \mathrm{~d}, \mathrm{~J} \mathrm{p}-\mathrm{p}=28.82 \mathrm{~Hz}) ;{ }^{13} \mathrm{C}$ NMR $\left(\mathrm{CDCl}_{3}\right) \delta 161.4(\mathrm{~s}, \mathrm{SCN}), 145.4-125.1\left(\mathrm{~m}, \mathrm{Ph}\right.$ and $\mathrm{C}_{\alpha}$ $\left.\mathrm{C}_{\beta}\right), 111.5(\mathrm{CN}), 84.5(\mathrm{Cp}), 29.6,29.2\left(2 \mathrm{t}, \mathrm{PCH}_{2} \mathrm{CH}_{2} \mathrm{P}, \mathrm{J} \mathrm{c}-\mathrm{P}=\right.$ $10.5 \mathrm{~Hz}) ; \mathrm{MS}\left(\mathrm{m} / \mathrm{z}, \mathrm{Ru}^{102}\right) 916.2\left(\mathrm{M}^{+}\right), 565.1\left(\mathrm{M}^{+}-\mathrm{CCPh}-\right.$ PhNCS - $\mathrm{CHC}_{6} \mathrm{H}_{4} \mathrm{CN}$ ). Anal. Calcd for $\mathrm{C}_{54} \mathrm{H}_{44} \mathrm{~N}_{2} \mathrm{P}_{2} \mathrm{SRu}$ (915.98): C, 70.80; H, 4.84; N, 3.06. Found: C, 70.59; H, 4.48; $\mathrm{N}, 3.12$. Spectroscopic data for $7 \mathrm{c}$ : ${ }^{1} \mathrm{H}$ NMR $\left(\mathrm{CDCl}_{3}\right) \delta 7.67-$ $6.08(\mathrm{~m}, 34 \mathrm{H}, \mathrm{Ph}), 3.94(\mathrm{~s}, 5 \mathrm{H}, \mathrm{Cp}), 3.09,2.75(2 \mathrm{~m}, 5 \mathrm{H}, \mathrm{CH}$

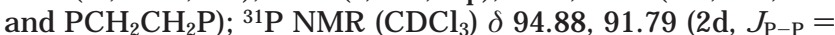
$18.27 \mathrm{~Hz}) ;{ }^{13} \mathrm{C}$ NMR $\left(\mathrm{CDCl}_{3}\right) \delta 182.0(\mathrm{CS}), 143.4-119.8(\mathrm{Ph}$ and $\left.\mathrm{C}_{\alpha}, \mathrm{C}_{\beta}\right), 108.6(\mathrm{CN}), 84.1(\mathrm{Cp}), 31.4,30.9\left(2 \mathrm{t}, \mathrm{PCH}_{2} \mathrm{CH}_{2} \mathrm{P}\right.$, $\left.J_{c-p}=15.4 \mathrm{~Hz}\right), 28.7(\mathrm{~s}, \mathrm{CH}) ; \mathrm{MS}\left(\mathrm{m} / \mathrm{z}, \mathrm{Ru}^{102}\right) 917.2\left(\mathrm{M}^{+}+1\right)$, $565.0\left(\mathrm{M}^{+}-\mathrm{CCPh}-\mathrm{PhNCS}-\mathrm{CHC}_{6} \mathrm{H}_{4} \mathrm{CN}\right)$. Anal. Calcd for $\mathrm{C}_{54} \mathrm{H}_{44} \mathrm{~N}_{2} \mathrm{P}_{2} \mathrm{SRu}$ (915.98): C, 70.80; $\mathrm{H}, 4.84 ; \mathrm{N}, 3.06$. Found: C, 71.29; H, 4.92; N, 2.91 .

Synthesis of $[\mathrm{Ru}]-\mathrm{C}=\mathrm{C}(\mathbf{P h}) \mathrm{C}(=\mathbf{S}) \mathbf{N}(\mathbf{P h}) \mathbf{C H P h}(\mathbf{7 d})$. To a $20 \mathrm{~mL} \mathrm{CH}{ }_{2} \mathrm{Cl}_{2}$ solution of $\mathbf{3 d}$ and $\mathbf{4 d}(200 \mathrm{mg}, 0.206 \mathrm{mmol}$, 3d:4d = 6:5) was added NaOMe $(55.6 \mathrm{mg}, 1.03 \mathrm{mmol})$. The mixture was stirred at room temperature for $30 \mathrm{~min}$ to give an orange-yellow solution. The 31P NMR spectrum of the solution indicated that $\mathbf{4 d}$ di sappeared but $\mathbf{3 d}$ was inert. Then the solvent was removed under vacuum and the residue was extracted with $3 \times 20 \mathrm{~mL}$ of hexane. After filtration, the solvent was removed under vacuum to give the yel low product

$[\mathrm{Ru}]-\mathrm{C}=\mathrm{C}(\mathrm{Ph}) \mathrm{C}(=\mathrm{S}) \mathrm{N}(\mathrm{Ph}) \mathrm{CHPh}(\mathbf{7 d} ; 45.8 \mathrm{mg})$ in $55 \%$ yield based on $\mathbf{4 d}$. Spectroscopic data for $\mathbf{7 d}$ : ${ }^{1} \mathrm{H} \mathrm{NMR}\left(\mathrm{CDCl}_{3}\right) \delta$ 7.78-6.15 (m, 35H, Ph), $4.87(\mathrm{~s}, 5 \mathrm{H}, \mathrm{Cp}), 2.91(\mathrm{~s}, \mathrm{H}, \mathrm{CH}), 2.50$ $2.15\left(\mathrm{~m}, 4 \mathrm{H}, \mathrm{PCH}_{2} \mathrm{CH}_{2} \mathrm{P}\right)$; ${ }^{31} \mathrm{P} \mathrm{NMR}\left(\mathrm{CDCl}_{3}\right) \delta 92.61,87.11(2 \mathrm{~d}$, J p-p $=21.7 \mathrm{~Hz}) ;{ }^{13} \mathrm{C} \mathrm{NMR}\left(\mathrm{CDCl}_{3}\right) \delta 183.4(\mathrm{SCN}), 150.3$, 146.1-121.8 (Ph, $\mathrm{C}_{\alpha}$ and $\left.\mathrm{C}_{\beta}\right), 83.6(\mathrm{Cp}), 34.6(\mathrm{~s}, \mathrm{CH}), 31.4(\mathrm{t}$, $\mathrm{PCH}_{2} \mathrm{CH}_{2} \mathrm{P}$, J $\left.\mathrm{c}-\mathrm{P}=23.4 \mathrm{~Hz}\right), 30.3\left(\mathrm{t}, \mathrm{PCH}_{2} \mathrm{CH}_{2} \mathrm{P}\right.$, J c-p $=24.5$ $\mathrm{Hz}) ; \mathrm{MS}\left(\mathrm{m} / \mathrm{z}, \mathrm{Ru}^{102}\right) 892.1\left(\mathrm{M}^{+}+1\right), 565.0\left(\mathrm{M}^{+}-\mathrm{CCPh}-\right.$ PhNCS $-\mathrm{CHC}_{6} \mathrm{H}_{5}$ ). Anal. Calcd for $\mathrm{C}_{53} \mathrm{H}_{45} \mathrm{NP}_{2} \mathrm{SRu}$ (890.98): C, 71.44; H, 5.09; N, 1.57. Found: C, 72.02; H, 4.88; N, 1.52. 
Table 3. Crystal and Intensity Collection Data for

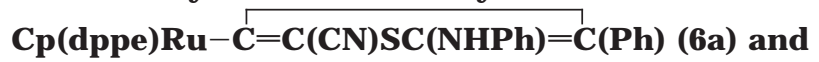
$\mathrm{Cp}(\mathrm{dppe}) \mathrm{Ru}-\mathrm{C}=\mathrm{C}(\mathrm{Ph}) \mathrm{C}(=\mathrm{S}) \mathrm{N}(\mathrm{Ph}) \mathrm{CH}\left(\mathrm{p}-\mathrm{C}_{6} \mathrm{H}_{4} \mathrm{CN}\right)$ (7c)

\begin{tabular}{|c|c|c|}
\hline & $6 \mathbf{a}$ & 7c \\
\hline mol formula & $\mathrm{C}_{48} \mathrm{H}_{40} \mathrm{~N}_{2} \mathrm{P}_{2} \mathrm{RuS}$ & $\mathrm{C}_{54} \mathrm{H}_{44} \mathrm{~N}_{2} \mathrm{P}_{2} \mathrm{RuS}$ \\
\hline space group & $\mathrm{P} 21 / \mathrm{n}$ & $\mathrm{P} 2 \mathrm{l} / \mathrm{n}$ \\
\hline cryst syst & monoclinic & monoclinic \\
\hline & $12.5271(2)$ & $14.6039(4)$ \\
\hline$b, \AA$ & 18.9824(3) & 18.9631(6) \\
\hline$c, \AA$ & $16.9845(2)$ & $16.7659(5)$ \\
\hline$\beta$, deg & $101.6490(10)$ & $97.503(1)$ \\
\hline $\mathrm{V}, \AA^{3}$ & $3955.63(10)$ & $4603.3(2)$ \\
\hline Z & 4 & 4 \\
\hline cryst dimens, $\mathrm{mm}^{3}$ & $0.15 \times 0.10 \times 0.10$ & $0.20 \times 0.20 \times 0$ \\
\hline $2 \theta$ range, deg & $1.63-26.38$ & $1.63-25.00$ \\
\hline indep/total no. of rflns & 805 & $8110 / 1$ \\
\hline abs cc & 0.5 & 0.4 \\
\hline max/min transmissn & $0.8622 / 0.6919$ & $0.8621 / 0.7560$ \\
\hline final R indices $(I>2 \sigma(I))$ & $\begin{array}{l}R 1=0.0461 \\
w R 2=0.0829\end{array}$ & $\begin{array}{l}\mathrm{R} 1=0.0438 \\
\mathrm{wR} 2=0.0848\end{array}$ \\
\hline R indices (all data) & $\begin{array}{l}\mathrm{R} 1=0.0853 \\
\mathrm{R} 2=0.0969\end{array}$ & $\mathrm{R} 1=0.0850$ \\
\hline largest diff peak, e $\AA^{-3}$ & $0.389 /-0.433$ & $0.398 /-0.408$ \\
\hline
\end{tabular}

X-ray Crystal Structure Analysis. The crystal structures of $\mathbf{6 a}$ and $7 \mathbf{c}$ were determined with a Siemens P4 diffracto- meter equipped with a CCD area detector and controlled by SMART version 4 software. Data reduction was carried out by SAINT version 4 and included profile analysis; this was followed by absorption correction using the program SADABS. Data were collected at $22{ }^{\circ} \mathrm{C}$ with Mo $\mathrm{K} \alpha$ radiation. The structures were determined by direct methods and refined using the SHELXTL version 5 package. Hydrogen atoms were introduced in ideal positions, riding on the carbon atom to which they are bonded; each was refined with isotropic temperature factors ranging from $20 \%$ to $50 \%$ greater than that of the ridden atom. All other atoms were refined with anisotropic thermal parameters. Pertinent crystal data are listed in Table 3.

Acknowledgment. We are grateful for support of this work by the National Science Council, Taiwan, Republic of China.

Supporting Information Available: Details of the structural determination for complexes $\mathbf{6} \mathbf{a}$ and $\mathbf{7 c}$, including tables of crystal and intensity collection data, positional and anisotropic thermal parameters, and all of the bond distances and angles. This material is available free of charge via the Internet at http://pubs.acs.org.

OM9901978 